\title{
Agata Szepe
}

\section{JEWISH-ISRAELI PAPERCUTTING IN THE LIGHT OF ACTOR-NETWORK THEORY. TRACING THE CHAIN OF TRANSFORMATIONS IN ETHNOGRAPHIC RESEARCH}

\begin{abstract}
The paper shows the chains of transformations that enabled a little-known art of papercutting to become a subject of ethnographic research in Israel. The main assumptions of the actor network-theory are presented. The meaning of "circulating reverence" and "chain of reference" is described. The crucial role of "representative guarantors" in the chain of reference on ethnographic research on Jewish papercut from the beginning of $20^{\text {th }}$ century is shown. The role of the center of calculation is presented. The chain breakdown during the Second World War is described. The development of papercutting network in Israel as well as the strategies of Israeli ethnographers to continue the research are depicted. The new perspectives that ANT approach gives on ethnographic research on the papercutting in Israel are summarised.
\end{abstract}

Keywords: ethnography, Israel, Actor-Network Theory, Bruno Latour, chain of references, Jewish papercut, papercutting in modern Israel

The aim of the text is to show how a little-known art of papercutting became a subject of ethnographic research in Israel. The article is a case study of a chain of transformations in ethnographic research on papercutting. Although Israeli papercutting can be easily linked with the traditional Jewish papercut, the fact that Israeli ethnographers made it a significant part of their research is far from obvious. Researched by European ethnographers in the pre-war period, Jewish papercut was a folk, mainly non-commercial form of art, popular among European Jews. Common mainly in the $19^{\text {th }}$ and the first half of the $20^{\text {th }}$ century, it was distinguished by its symbolic, unique motives and association with religion. ${ }^{1}$

1 G. Frankel, The Art of Jewish Papercut, MODAN Publishing House, Tel Aviv 1996, p. 11. The art of Jewish papercutting was popular among the Jews in Europe, Middle East and America especially in the $19^{\text {th }}$ century and at the beginning of the $20^{\text {th }}$ century. In Central and Eastern Europe a distinctive style of Ashkenazi papercut was developed. It contained usually both visual elements which had symbolic significance and texts from the Hebrew Bible and other Jewish religious writings. Already at the beginning of the $20^{\text {th }}$ century ethnographers classified Jewish papercuts unto different types according to their features and functions. An example can be Shivis' $i$, a papercut that was hung on 
On the contrary, papercutting in modern Israel is both commercial and non-commercial art, with a wide range of motives and styles, usually not associated with religion. Being made by professional and not folk artists, it is created in a different place, time and cultural context than the pre-war folk art.

To understand what exactly led to the popularity of papercutting among Israeli researchers we need a methodological approach that will enable us to understand the complexity of more than thousand years old cultural and social processes. I claim that the actor network-theory will put a new light on the character of the ethnographic research in Israel.

\section{Methodological Assumptions of the Article}

The actor network-theory, frequently abbreviated as ANT, is both a research project and a philosophical concept initiated in 70 s by the philosopher and social researcher Bruno Latour. ${ }^{2}$ As other important ANT researchers can be mention Michel Callon and John Law. ${ }^{3}$ At the outset applied mainly to the studies on technology and science, ${ }^{4}$ it started to be used in other research fields such as sociology, ${ }^{5}$ archaeology, ${ }^{6}$ cultural anthropology, ${ }^{7}$ as well as ethnography. ${ }^{8}$

The main assumption of the ANT is to look on the researched phenomena as on a network of related actors, influencing ceaselessly one another. The philosophical

the east wall of the house to show the direction of Jerusalem, the direction that religious Jews face during the prayer. In poorer synagogues a board called Mizrah that served similar purpose, was made in a form of a papercut. Other examples can be papercuts created for religious celebrations such as Shevuoslekh and Royzelekh for Shavuot festival or papercuts decorating a tent - Sukkah in the time of Sukkot celebrations. They were also used as amulets (e.g. Hamsa) or decorated traditional Jewish marriage contract called Ketubah. See: G. Frankel, Wycinanka żydowska w Polsce, Towarzystwo Ludoznawcze, Lwów 1929.

2 K. Abriszewski, Poznanie, zbiorowość, polityka, Universitas, Kraków 2012, p. VI.

3 Ibidem, p. 8. In my article I will focus on the approach presented by Bruno Latour, referring also to other researchers using the ANT approach.

4 See e.g. B. Latour, Where Are the Missing Masses? The Sociology of a Few Mundane Artifact, [in:] W. Bijker, J. Law (eds.), Shaping Technology/Building Society: Studies in Sociotechnical Change, MIT Press, Cambridge, MA-London 1992.

5 See e.g.: R. Shamir, Current Flow: The Electrification of Palestine, Stanford University Press, Stanford 2013 .

$6 \quad$ See e.g.: B. Olsen, Kultura materialna po tekście: przywracanie obecności rzeczom, [in:] E. Domańska (ed.), Teoria wiedzy o przeszłości na tle wspótczesnej humanistyki, Wydawnictwo Poznańskie, Poznań 2010.

7 K. Abriszewski, op. cit., p. VIII.

8 See e.g.: דני שרירא, איסוף שברי הגולה: חקר הפולקלור בישראל בשנות ה-04 וה-05, האוניברסיטה העברית בירושלים משלים ירושלים: 1102. דוקטורט הוגש לסנט האוניברסיטיטה 
concept of the ANT is described as a non-dualistic approach, i.e. as an approach which does not use any pairs of opposite concepts to describe the reality. ${ }^{9}$

Kien Grant, a researcher applying ANT to material culture studies, claims that the main purpose of the ANT researchers is transgressing the modernistic way of thinking, in which the world is divided unto separate, opposite categories:

They [Actor-Network theorists'] in fact dedicated themselves to transcending modernist paradigms that split the world into discrete conceptual realms set against one another, such as material versus metaphysical. ${ }^{10}$

It is a crucial fact, because a great majority of the western philosophy, the basic ways of academic thinking and even colloquial intuitions are based on creating this type of opposite concepts.

In my opinion getting out of the set patterns is the biggest difficulty in conducting the research using the ANT approach. Hence, I will pay a special attention to the potential of the Latourian version of non-dualistic way of thinking, showing each time examples from my research.

\section{Applying Latourian Non-Dualistic Way of Thinking to the Research}

Rejected by Bruno Latour, the fundamental pair of dualisms is subject and object. The former is usually described as an individual that act autonomously. According to the modern paradigm it belongs to the sphere of culture. The latter, deprived of the free will and agency, belongs to the opposing sphere of the nature. By ignoring this division, the French philosopher implements a category of an "actor". Actors can be humans as well as, so called by Latour, "non-humans". ${ }^{11}$ The category of non-humans includes, for instance, organisms, machines, groups of cooperating actors and institutions. Bruno Latour says:

I use — actor,\| — agent, $\|$ or — actant\| without making any assumptions about who they may be and what properties they are endowed with. (...) they have the key feature of being autonomous figures. Apart from this, they can be anything — individual (-Peterll) or collective (-the crowdll), figurative (anthropomorphic or zoomorphic) or nonfigurative (-fatell). ${ }^{12}$

9 For a good commentary to the dualistic and non-dualistic way of thinking see: K. Abriszewski, op. cit., pp. 15, 96-103.

10 G. Kien, Actor-Network Theory: Translation as Material Culture, 2009, https://grantkien.wordpress. com/2013/02/23/actor-network-theory-translation-as-material-culture-by-grant-kien-2009/ (access: 22.08.18), p. 27.

11 See e.g.: B. Latour, We Have Never Been Modern, Harvard University Press, Cambridge, MA 1993, p. 11.

12 See e.g.: B. Latour, The Pasteurization of France, Harvard University Press, Cambridge, MA-London 1988 , p. 252 n. 
Following this way of thinking, in my article I pay attention both to human actors such as ethnographers or artists and to non-humans such as a paper, a scanner, a camera, or an archive building. It is not the ontological status of the actor, but his influence on other actors, that makes him important in the light of the Actor-Network Theory. According to Bruno Latour an actor is somebody or something that impacts other actors: "the key is to define the actor by what it does - its performances". ${ }^{13}$

Bruno Latour postulates ignoring an aspect of the "free will" and "intentional acting" in the researched net. For example, if working of a machine or other object influences significantly other actors, it should be seen as significant, even if it cannot be interpreted as a deliberate action. Latour says:

This is not to say that machines think like people do and decide how they will act, but their behaviour or nature often has a comparable role. Actor network theorists argue that the material world pushes back on people because of its physical structure and design. ${ }^{14}$

Applied to my research, the strategy of resigning from subject-object opposition enables me to notice that, although they are often ignored in social or cultural research, physical properties of an object or the way that they work, can distinctly influence the turn of events. As it will be demonstrated later, the physical properties of papercuts, such as fragility, turned out to be one of the biggest threats to the continuity of the research. What is more, the objects used to reproducing papercuts were not less essential to the research than the will of human actors to conduct it.

The next important division intentionally ignored by Latour is a dualistic division on the local and global sphere. Removing this division can be understood as a consequence of implementing the actor-network category. If the world is understood as a set of relations, each of the connections between the actors is of the same importance. Tracing the net of interactions, Latour is not willing to use concepts popular in an academic research such as: society, culture, social phenomenon. The reason for this is that according to him this type of concepts attempts to describe in a "global" and simplified way a part of the "local" reality. According to the researcher, the problem is that concepts of this type are inexact. To understand truly the complex mechanisms, we need to focus on the net of interactions instead of debating the abstract, generalizing concepts. Latour claims:

We have to lay continuous connections leading from the local interaction to the other places, times and agencies through which a local site is made to do something. (...) If we do this, we

13 Ibidem, p. 303. See also: ACTOR/ACTANT: “(...) Since in English 'actor' is often limited to humans, the world 'actant' borrowed from semiotics, is sometimes used to include nonhumans in the definition". Ibidem, p. 303.

14 B. Latour, Where Are the Missing Masses?..., op. cit., p. 151. See also: "Those advocating the actor-network approach agree with the social constructivist claim that sociotechnical systems are developed through negotiations between people, institutions, and organizations. But they make the additional interesting argument that artifacts are part of these negotiations as well". Ibidem. 
will render visible the long chains of actors linking sites to one another without missing a single step. $^{15}$

Instead of focusing on abstract concepts, I will therefore describe in my article a range of interactions. To describe the character of the interactions in the net, I will use a Latourian concept of the "chain of transformations". Showing the complexity of the relations, I will intentionally avoid moving from the detailed examples to the general, "global" terms.

In the same way, I will avoid differentiating between the micro and the macro scale ${ }^{16}$ moving fluently between descriptions of the single objects, such as an original of a papercut, to more complex systems, such as an archive or a group of ethnographers. This way of thinking will enable us to understand how the local reality of pre-war ethnographic research on Jewish papercut led to a development of equally local research on papercutting in modern Israel.

In the main part of this article, I will attempt to create the text that in the Latourian categories could be called a good description: ${ }^{17}$ a solid, precise and accurate observation of the network, without putting it in a theoretical frame of non-Latourian abstract concepts. In the conclusive part, I will demonstrate how the good description can show this interesting part of modern Israeli reality from a new perspective.

Regardless of seeing it as an advantage or a weakness, a description in Latourian understanding is always an observation of a unique combination of relations, a case study. ${ }^{18}$ In compliance with this methodological approach, I will focus on the case study of the chain of transformations in ethnographic research on the papercutting. In my opinion, the chosen case is worth describing for two major reasons.

Firstly, because the particular case of the ethnographic research shows that the Latourian idea of the "chain of transformations" can be observed in various fields of research. In the publication the Pandora's Hope Bruno Latour depicts in a comprehensive way an idea of the chain of transformations using as an example a case study from natural science. ${ }^{19}$ The ethnographic research is usually seen as belonging to the domain of social science. Tracing the chain of reference in ethnography can suggest, therefore, that the practices of natural and social science can have more in common than it is usually thought.

15 B. Latour, Reassembling the Social: An Introduction to Actor-Network-Theory, Oxford University Press, New York 2005, p. 173.

16 For further comments about theoretical issues associated with the local and the global see: First Move: Localizing the Global [in:] ibidem, pp. 173-190.

17 Ibidem, p. 144.

18 Latour seems to be uninterested in outreaching the domain of case studies: "If something is simply an 'instance of' some other state of affairs, go study this state of affairs instead. A case study that needs a frame in addition, well, it is a case study that was badly chosen to begin with!" Ibidem, p. 143.

19 B. Latour, Pandora's Hope: Essays on the Reality of Science Studies, Harvard University Press, Cambridge 1999, pp. 24-79. 
Secondly, the chosen case enables one to observe what happens when the researchers, instead of building the chain all the way through, have to cope with its rapid breakdown. The observation of the consequences of the chain breakdown can be seen as an innovative attempt.

Bruno Latour says:

The only way to understand the reality of science studies is to follow what science studies does best, that is, paying close attention to the details of scientific practice. ${ }^{20}$

Only the close look on the ethnographic research practices enables one to understand better how the studies on papercutting developed in Israel.

\section{The Chain of References in Ethnographical Research on Papercut}

Bruno Latour pays attention to the fact, that in the academic research process one cannot directly translate the reality unto his scientific description. Instead, the scientists create a chain of intermediate stages where each time the researcher reshapes the reality, simultaneously preserving the truth value on the researched subject. Following Latour, I will call the intermediate stages a „reference” or a „circulating reference, ${ }^{21}$ while all the stages together a "chain of transformations" 22 or a "chain of references". ${ }^{23}$ Latour states:

The word "reference" designates the quality of the chain in its entirety, and no longer adequatio rei et intellectus. Truth-value circulates here like electricity through a wire, so long as this circuit is not interrupted. ${ }^{24}$

For instance, a map of a region is a reshaped image of the particular piece of land. A map refers to the land not because it reflects accurately the reality, but by conveying truth about the researched object. On each stage, more scientific knowledge is gained. ${ }^{25}$ Only after a series of transformations the academics come to the last reference, most frequently a verbal expression of the results of research in an academic publication. ${ }^{26}$ The scientists consider each of the intermediate stages as a reference to the researched reality.

$20 \quad$ Ibidem, p. 24.

21 See e.g.: "The old settlement started from a gap between words and the world, and then tried to construct a tiny footbridge over this chasm through a risky correspondence between what were understood as totally different ontological domains - language and nature. I want to show that there is (...) an entirely different phenomenon: circulating reference". Ibidem, p. 24.

22 Ibidem, p. 70.

23 Ibidem, p. 69.

24 Ibidem, p. 69.

25 K. Abriszewski, op. cit., p. 42.

26 Bruno Latour gives an example of a chain of references in the Pandora's Hope: "Space becomes a table chart, the table chart becomes a cabinet, a cabinet becomes a concept, a concept becomes an institution”. B. Latour, Pandora's Hope..., op. cit., p. 36. 
Adhering to the main assumption of the ANT methodology, I will analyse the chain of references, leading to the ethnographic research on papercutting in modern Israel. As it will be displayed below, at the beginning, the chain of references in the papercut research could be described as a typical to a research process. Yet at one point the chain was rapidly broken. In the further part of my text, I will show the character of the chain breakdown as well as the research strategies that helped the ethnographers to reconstruct the chain. Having in mind that the modern Israeli papercutting is seen by Israeli ethnographers as an art that continues the tradition of the pre-war folk Jewish papercut, I will begin to track the chain of references in the pre-war ethnographic research on Jewish papercut.

\section{Initial Stages: Collecting Representative Guarantors}

Ethnographic interest in Jewish papercutting grew in the beginning of the $20^{\text {th }}$ century. In compliance with the rules of the ethnographic research, scholars determined the part of the reality they referred to. According to Bruno Latour this stage happens usually at the beginning of the academic research:

As soon as we go into the field or turn on an instrument, we find ourselves drowning in a sea of data (...) The pace must be accelerated if we are to avoid being overwhelmed by worlds of trees, plants, leaves, paper, text. Knowledge derives from such movements, not from simple contemplation of the forest. ${ }^{27}$

The interest of the ethnographers focused on the papercutting as a folk form of European Jews art. After determining the field of interest, the ethnographers started to collect the works of art similarly to the biologists collecting samples of trees, plants and leaf. Referring directly to the phenomenon of Jewish papercutting, the original papercuts became for the ethnographers the first reference in the chain they wanted to build. Giving an example of a researcher collecting data, Bruno Latour calls the samples a representative guarantor of the reality:

The forest cannot directly give its credit to Edileusa's text, but she can be credited indirectly through the extraction of a representative guarantor, neatly preserved and tagged, that can be transported, along with her notes, to her collection at the university in Boa Vista. ${ }^{28}$

In the same way, the originals of Jewish papercuts were established a representative guarantor of the papercutting practice. And because already in the interwar period the folk art of papercutting started to fade out, the ethnographers struggled to collect as much as possible, similarly to biologists, trying to document an endangered species. Although they were playing an important role in the chain of transformations, the original papercuts could not become the last stage in the research.

27 Ibidem, p. 39.

28 Ibidem, p. 34. 
Being extremely fragile, the papercuts were photographed by the ethnographers in a case the originals would be destroyed. The photography became a reference to the original piece of art. Moreover, because the folk artists were not always willing to give or sell their works, the number of original papercuts that ethnographers were able to collect was further diminished. Therefore, sometimes only a photography was transferred to the collection, because taking the original papercut was impossible. The academics didn't need to use the fragile papercuts to the next stages of the research. Instead, they preferred the copies, a reference to the originals. In the same way that a single piece of plant, collected by a botanist: "represents thousands of the same species present in the forest", ${ }^{29}$ the copies referred directly to the original papercuts and indirectly - to the practice of papercutting among the Jews in the pre-war period.

The next stage of building the chain of transformations can be reconstructed by looking on the academic publications on Jewish papercut, especially the most comprehensive monography on the pre-war papercutting: Wycinanka żydowska w Polsce [Eng. Jewish Papercut in Poland $]^{30}$ by Giza Frankel. ${ }^{31}$ The author describes there the most popular motives, symbols and inscriptions on Jewish papercuts, categorized according to their function and connection with Jewish holidays.

The way in which the material is arranged in the book suggests, that the collection of original and copied papercuts was sorted out according to repetitive patterns, motives and functions. According to Bruno Latour, one of the crucial stages in building the chain of references is gathering in one place all the arranged references "from different locations and times that become contemporaries of one another on the flat table, all visible under the same unifying gaze". ${ }^{32}$

Only after the arranging, the representative guarantors of the Jewish papercutting practice the ethnographers were able to draw conclusions, depicted in academic articles. Till the Second Word War a couple of articles on Jewish papercut were published, creating the next circulating reference to the researched phenomenon. ${ }^{33}$ The originals and copies of the Jewish papercuts either remained in private collections or where transferred to archives, described by Bruno Latour as a typical place, where the representative guarantors are preserved.

\footnotetext{
Ibidem, p. 32.

Translation mine.

G. Frankel, Wycinanka żydowska..., op. cit.

B. Latour, Pandora's Hope..., op. cit., p. 38.

E.g. R. Liliental, Święta żydowskie w przeszłości i w teraźniejszości, Akademia Umiejętności, Kraków 1919; M. Goldstein, Kultura i sztuka ludu żydowskiego na ziemiach polskich, Książnica-Atlas, Lwów 1935; G. Frankel, Wycinanka żydowska ..., op. cit.
} 


\section{The Role of Archives as Latourian Centres of Calculation}

Being a place where the researchers come to analyse all over again the collected data, the archives can be seen as a role model of Latourian centres of calculation. ${ }^{34}$ According to Bruno Latour:

Center of calculation is any site where inscriptions ${ }^{35}$ are combined and make possible a type of calculation. It can be a laboratory, a statistical institution, the files of a geographer and so forth. The expression locates in specific sites an ability to calculate that is too often placed in the mind. ${ }^{36}$

Extending gradually the scientific resources preserved in archives, the researchers gain an access to the wider knowledge. A collection of arranged representative guarantors makes the next explorations much easier.

\section{The Chain Breakdown}

To this very moment everything went according to Latourian expectations. It could be expected that in the next stage the researchers, who gained more knowledge in the centres of calculation, will return to the field work and collect another portion of representative guarantors.

However, the process was rapidly interrupted. The traditional, folk art of papercutting gradually faded out already in the interwar period, being destroyed almost completely during the Holocaust, when most of the folk artists where murdered. Located in archives, private collections and kept by the authors, most of the papercuts where destroyed in the Second World War. Emphasized by the ANT researchers, the influence of physical properties of the objects on the reality is in this case more than obvious. Being in and of itself a fragile material, the paper became even more delicate, when the sophisticated patterns where cut in it. Hence, the papercuts had slimmer chances to survive the war than objects made from other material, e.g. metal. Krzysztof Abriszewski notices the importance of the continuity in the chain of references:

If the Amazonian expedition for some reasons lost all data, samples, notes and drafts, it would become valueless from the scientific point of view. If the diligently prepared research on fundamentals of politics stopped on interviewing the answerers and completing questionnaires, yet the questionnaires itself got lost (...) the research would not be worth a red cent. ${ }^{37}$

34 K. Abriszewski, op. cit., p. 56.

35 According to Latour an inscription is: "a general term that refers to all the types of transformations through which an entity becomes materialized into a sign, an archive, a document, a piece of paper, a trace". See: p. 306.

36 B. Latour, Pandora's Hope..., op. cit., p. 304.

37 K. Abriszewski, op. cit., p. 53: "Gdyby wyprawa amazońska z jakichś powodów utraciła wszystkie dane, próbki, notatki i szkice, to z punktu widzenia nauki stałaby się bezwartościowa. Gdyby skru- 
The chain breakdown had crucial consequences to the further research. Bruno Latour claims that the research requires a flow of new representative guarantors to continue the research at all.

\section{Continuing Research on the Surviving Material}

Being unable to get an access to the lost world of Jewish papercut, the ethnographers adopted some strategies to overcome the impasse. Firstly, the research on the little number of remained representative guaranties was continued. The ethnographer Giza Frankel managed to preserve an amount of research material. Emigrating in 50s from Poland to Israel, she became a crucial actor in the Israeli papercutting network, popularizing this form of art among Israeli artists.

Professor Goldberg describes, that after Giza Frankel's death, her daughter conveyed the collection to professor Neuman, who gave most of it to professor Goldberg. Owning the collection of representative guarantors, professor Goldberg was able to continue the research, initiated by Giza Frankel. She created an archive of papercut at the Hebrew University. Another collection of pre-war papercuts gathered by Judith and Joseph Shadur was placed in the Israeli Museum as the Judith Shadur Archive.

It is important to notice, that neither in the University nor in the Israeli Museum Archive have I found originals of pre-war papercuts. According to professor Olga Goldberg, most of the objects, that survived in the collection where not original papercuts, but their copies. ${ }^{38}$ The fragmentary character of the archive challenges the traditional understanding of this institution in ethnographic research. The Latourian observation of creating an archive questions the hope of traditional ethnography and anthropological studies in general, to create an objective representation of a part of the reality. ${ }^{39}$ It can be seen as closer to the postmodern understanding of the archive as a result of many factors. The postmodern approaches see:

[T]he historical record, whether it consists of books in libraries or records in archives, not as an objective representation of the past, but rather as a selection of objects that have been preserved for a variety of reasons (which may include sheer luck) (...) Whatever the archive contains is already a reconstruction — a recording of history from a particular perspective. ${ }^{40}$

pulatnie przygotowane badania podstaw politycznych zatrzymały się na przeprowadzeniu wywiadów $\mathrm{z}$ respondentami i wypełnieniu ankiet, a same ankiety zginęły (...) same badania nie byłyby warte złamanego grosza”. Translation mine.

38 According to information in conversation conducted with Olga Goldberg.

39 For more information about the discussion on objectiveness of an ethnographic archive see e.g.: K.H. Kohl, The Future of Anthropology Lies in Its Own Past: A Plea for the Ethnographic Archive, "Social Research" 2004, Vol. 81 (3).

40 M. Manoff, Theories of the Archive from Across the Disciplines, Portal Libraries and the Academy, 2004, Vol. 4 (1), p. 14. 
The ANT approach challenges, however, also the postmodern view: instead of one particular perspective it multiplies the perspectives of various actors. Hence, trying not to overlook the great conscious effort that the ethnographers made to create the archive, I will see the collection gathered in the archive as a result of both conscious human action and the influence of the non-human actors. The obscure term of "sheer luck" can be therefore replaced with an intervention of various non-human actors and their features. The physical properties of the papercuts and their copies or the capability of reproducing using various coping devices will be crucial to the process of creating an archive.

Although the original papercuts do have for the researchers a value as the closest reference to the reality of the pre-war folk art, the copies of the papercuts are sufficient to the continuation of the research on Jewish papercut. Sorted out, inserted to compartments in the two main archives, they became signs which the ethnographers educe and articulate. ${ }^{41}$ It turned out that the copies are even more convenient for the research, because they are less fragile than the originals. New technologies brought even more convenient safety devices. The papercuts can be scanned and saved on the computer or potable memory. The researchers continue the practice of collecting signs: the collection of modern Israeli papercut contains a great number of copies. When the originals for some reason are not available, they are the only reference to a papercut.

The collection of Jewish papercut in Israeli archives enabled the Israeli ethnographers to publish some significant works on this pre-war folk art. Giza Frankel wrote in Israel a Hebrew-English monography on Jewish papercut, Migzerot neyar. Omanut jehudit amamit ${ }^{42}$ [Eng. Papercuts. Jewish Folk Art $]^{43}$ with reproductions of many pre-war papercuts. Joseph and Judith Shadur publications: Jewish Papercut: A History and Guide ${ }^{44}$ and Traditional Jewish Papercuts. An Inner World of Art and Symbol ${ }^{45}$ became important works on traditional Jewish papercut and another actor in the papercutting network.

Nevertheless, the research on the pre-war folk art is possible only to some extent. The number of pre-war papercuts that still can be discovered is limited. The ethno-

41 See e.g. the description how a lump of earth becomes to the scientist a sign: "Consider this lump of earth. Grasped by Rene's right hand, it retains all the materiality of soil: 'ashes to ashes, dust to dust.' Yet as it is placed inside the cardboard cube in Rene's left hand, the earth becomes a sign, takes on a geometrical form, becomes the carries of a numbered code, and be soon defined by a color. (...) We focus the reader's attention on this hybrid, this moment of substitution, the very instant when the future sign is abstracted from the soil. (...) And yet Rene does not impose predetermined categories on a shapeless horizon: he loads his pedocomprator with the meaning of the piece of earth - he educes it, he articulates it". B. Latour, Pandora's Hope ..., op. cit., pp. 50-51.

42 G. Frankel, The Art of Jewish Papercut, op. cit. Simplified phonetic transcription from Hebrew.

43 Translation mine.

44 J. Shadur, Y. Shadur, Jewish Papercut: A History and Guide, Gefen, New York 1994.

45 J. Shadur, Y. Shadur, Traditional Jewish Papercuts: An Inner World of Art and Symbol, University Press of New England, Hannover 2002. 
graphers cannot simply return to the places where traditional Jewish papercut is practiced. Bruno Latour emphasises the significance of making one's way back:

To know is not simply to explore, but rather is to be able to make our way back over our own footsteps, following the path you have just marked out. ${ }^{46}$

In the case of Jewish papercut, the way to the world of traditional art is irreversibly lost. Yet, the research on remaining material concerning Jewish papercut led also to development in other than academic area what turned out to be crucial to continuing the research.

\section{The Development of Israeli Papercutting Network}

The activities of the ethnographers did not operate in a vacuum. Tracing further connections between the actors it can be noticed that the ethnographers inspired a group of artists in Israel to use creatively the technique and motives of traditional Jewish papercut. Firstly, through a direct contact with various people in Israel the ethnographers drew attention to this form of art. According to Professor Goldberg, Giza Frankel played an important role in popularizing papercuts in Israel. Aroused interest in papercutting lead to establishing the first informal group of papercutting artists in Haifa.

Secondly, the ethnographers formed an alliance with the non-human actors, especially books to reach a broader public. While most of the Israeli papercutters have a little or no contact with the collection in the archives of papercuts, they widely use publications on Jewish and international papercut. Written and published in Israel, the book Migzerot neyar. Omanut jehudit amamit by Giza Frankel became crucial actor that contributed to the development of Israeli papercutting network. Many of the Israeli modern artists which I interviewed ${ }^{47}$ see publications on Jewish papercut, especially the position of Giza Frankel, as an important part of their inspiration. For example, a modern Israeli papercutter David Fisher ${ }^{48}$ describes that he was inspirited to begin creating papercuts professionally by the book Migzerot neyar. Omanut jehudit amamit, that he received from his friend.

Other publications about the tradition Jewish papercut that have been published gradually, ${ }^{49}$ also contributed to the popularization of this art. In private libraries of modern Israeli papercutters, such as Naomi Shapira, ${ }^{50}$ Dani Azoulay ${ }^{51}$ and Rina

46 B. Latour, Pandora's Hope..., op. cit., p. 74.

47 A part of my research was based on interviews with the artists and researchers conducted entirely in Hebrew.

48 An interview with David Fisher was conducted on $18^{\text {th }}$ November 2015.

49 See e.g.: G. Frankel, The Art of Jewish Papercut, op. cit.; J. Shadur, Y. Shadur, Jewish Papercut..., op. cit.; J. Shadur, Y. Shadur, Traditional Jewish Papercuts..., op. cit.

50 An interview with Naomi Shapira was conducted on 27.11.2015.

51 An interview with Dani Azoulay was conducted on 2.12.2015. 
Biran, ${ }^{52}$ can be found many publications on modern and traditional papercut. The contact with the books led to creative usage of the material. Modern Israeli papercutter Henja Melichson ${ }^{53}$ wrote her own position about Jewish papercut, drawing on the already available sources. Rina Biran is both a researcher and a leader of Israeli papercutting association: Irgun Gozrej Nejar be-Israel..$^{54}$ Together with other researchers and artists they publish an annual about papercutting in modern Israel.

The net of papercutting activities started becoming tenser. The artists have been selling their works, organizing exhibitions and workshops. Also, an interest in a laser machine cutting technique gradually grew. An example of a craftsman who uses this technic is Dani Azoulay. Still an inherent element of this net is researching activities of the ethnographers. Some of the ethnographic researchers are at the same time papercutting artists. A good example can be Judith Shaddur, a well-known papercutting artist that together with her husband created an archive of Jewish papercut and contributed significantly to the research on traditional papercut. ${ }^{55}$ It could be said that the activities of the ethnographers and the modern Israeli artists reinforce each other.

\section{Rebuilding the Broken Chain of References}

A development of papercutting network in Israel enabled the Israeli ethnographers to create a second strategy to continue the research. They recognized the papercutting in modern Israel as a continuation of the Jewish papercut. In such a way, the field of research was widened. According to the professor Olga Goldberg, the papercutting is one of the few form of arts in Israel which are a continuation of the folk art. ${ }^{56}$

Indeed, the modern Israeli papercutting is linked with the folk Jewish papercut in various ways. Firstly, significant ethnographers, researching it moved after the Second World War to Israel. Moreover, there can be found also folk Jewish artists, who moved from Europe to Israel. For example, Josef Wiznicer after making alija continued creating papercuts. ${ }^{57}$ What is also important, the ethnographers researching on Jewish papercut made most significant contribution to the popularisation of the papercutting among Israeli artists. Finally, although the styles of the modern Israeli papercutting are much more diverse than the repetitive motives of the pre-war folk art and the art of papercutting itself is highly commercialised, still some inspirations from the Jewish papercut can be found among Israeli papercutters.

52 An interview with Rina Biran was conducted on 24.11.2015.

53 An interview with Henja Melichson was conducted on 5.02.2016.

54 For more information about the organization see: https://sites.google.com/site/israpapercuts/home/ about-the-organization (access: 24.08.2018).

55 About the art of Judit Shaddur see e.g.: http://www.shadurarts.com/about-yehudit-shadur/ (access: 24.08.2018).

56 According to information in conversation conducted with Olga Goldberg.

ויזניצר,יוסף,מגזרות / מעשי ידי, פנימי, תל-אביב: 349157 
All the aforementioned facts gave a theoretical basis to call the modern Israeli papercutting a continuation of the Jewish papercut. At the same time, I claim that the research could not be continued if the Israeli ethnographers did not make a physical link between the modern and old papercuts. They did it by putting both collections in the same centre of calculation. Occupying two rooms of the Folk Research Center at the Hebrew University, the archive of papercutting became a centre of calculation also for the modern Israeli art thanks to professor Olga Goldberg. Starting to collect the samples of modern papercuts in Israel, the researchers were able to place them in the archive.

Because the research was continued, most of the collection refers now to the modern papercutting in Israel. At the same time, various material referring to the pre-war Jewish papercut can be found in the same archives. Legitimising the theoretical intuitions, a physical link between the pre-war and modern papercut was created by putting the objects referring to the modern and pre-war art in the same rooms and sometimes even the same binders. It illustrates in a good way the type of relationship between the actors in the Latourian network. Bruno Latour claims that the net links always actors which various origins, durability and time of existence:

What is acting at the same moment in any place is coming from many other places, many distant materials, and many faraway actors. (...) the metaphor that she chooses is just six years old and this rhetoric trope straight out of Cicero; but the computer keyboard she has typed her speech on is fresh from Apple, although the heavy metals making possible the coordination of some of its switches will last for as long as the universe. Time is always folded. ${ }^{58}$

Representative guarantors in the archive refer to two different realities: the pre-war Europe and the modern Israel. Nevertheless, the institution of the archive enables the researchers to look on them: "all visible under the same unifying gaze". ${ }^{59}$ Once again, like in the time of pre-war research, the ethnographers managed to overcome the chaos of reality by cumulating various representative guarantors in a calculation centre. Tracing the network that led from the beginning of ethnographic research on papercut, we can see that through a sequence of modifications in the chain of references, the Israeli ethnographers managed to create such a condition, under which a research on the papercutting is possible and justified. The broken chain of references was rebuilt.

\section{What Can Be Learned from the Latourian Description}

The main purpose of the article was to describe the origins and factors of academic interests in papercutting among modern Israeli researchers in the light of the Actor-Network Theory. A practical effect of tracing various interactions, simultaneo-

58 B. Latour, Reassembling the Social..., op. cit., pp. 200-201.

59 B. Latour, Pandora's Hope..., op. cit., p. 38. 
usly avoiding using general, abstract terms, is a strongly empiric character of the article, with a significant part made of a precise description of various interactions from the beginning of ethnographic research on papercutting to the present day. According to the ANT, a researcher has to create an accurate and "thick" description of the network. Unusually detailed description might be held for naivety. Nevertheless, according to Actor-Network Theory researchers, it has a clear purpose: a solid observation enables one to understand the mechanisms, that could be overlooked when applying the theoretical instruments of the traditional sociology. According to Latour, we should not underestimate a good description:

For every hundred books of commentaries and arguments, there is only one of description. To describe, to be attentive to the concrete state of affairs, to find the uniquely adequate account of a given situation, I myself have always found this incredibly demanding. ${ }^{60}$

In academic articles written according to Latourian methodology one will search in vain for explaining the described nets by historical, social, cultural or psychological context. According to Latour a good description does not need this type of theoretical frameworks to explain the interactions between the actors.

In closing, I would like to point out some of conclusions that can be drawn from my observations. In such a way, I will try to demonstrate how a good description in a Latourian sense can show things that probably could be missed, when using a standard dualistic way of thinking.

The detailed description of a chain breakdown and its consequences shows foremost, that despite a catastrophe on an unpreceded scale, the possibility of continuation of the research on Jewish papercutting was not irretrievably lost. The first lesson can be very universal: maybe never in the history of humanity happened such a catastrophe in which everything that is researchable would be totally annihilated. To the continuation of the research on papercutting contributed both non-human and human actors. The former where preserved papercuts and their copies, the latter ethnographers which adopted certain strategies to rebuild the broken chain of transformations.

The first strategy can be described as continuing research on what remained. Regardless whether it came to the original papercuts, their copies or information about it, the Israeli ethnographers made a huge effort to sort it, put in centres of calculation, research on it and create publications. Directly the research led to deeper understanding of the traditional Jewish papercut phenomenon, indirectly - to the growing interest in papercutting among Israeli artists.

The second strategy can be formulated as including in the research other phenomena, that are similar from a scientific point of view. To include the modern Israeli papercut in the research it was both important to find scientific arguments to do so and to make a physical link between them and the traditional Jewish papercut.

60 B. Latour, Reassembling the Social..., op. cit., p. 144. 
The physical link was made by putting the modern papercuts in the same centre of calculation that the pre-war items and continuing the research on the actors from both realities. Placing the old and the modern papercuts in the same archive justified the researcher's assumption to see the modern Israeli papercut as a continuation of the Jewish folk art. It confirms the Latourian observation, that the archive is a centre of calculation that enables next research cycles.

Observing the way of reassembling the broken chain of references in ethnographic research on Jewish papercut enables one to understand that seeing the Israeli papercut as a continuation of the old folk art is not the only possible research assumption, yet there are some good arguments that support it. The assumption gives the ethnographers a solid base to recognise the research on Israeli papercut not as an eccentric idea, beyond the borders of the science, but as a research field with a solid academic background.

Moreover, the Latourian focus on the influence of the actors, regardless if they act intentionally or not, shows that the modern research on the papercut would not develop in Israel without a number of non-human actors: objects such as camera, photocopier and scanner. Already from the beginning of the research on the papercuts the new technologies made possible its continuation. Due to various objects academics are able to continue the research both on the pre-war and modern papercutting. The main medium of the ethnographic research on papercuts is not the original papercut, but a collection of objects-mediators, ${ }^{61}$ created in a process of copying. Apparently, despite the value of original papercuts, the ethnographers need above all this copies-signs to continue the research. Sorted, structured and placed in the archives, they are a good reference to the practice of papercutting. The question if the originals remained or were destroyed is less important from the ethnographic point of view.

Furthermore, tracking the chain of reference shows that the researchers willing to link the pre-war European Jewish culture with the Israeli one will always have to cope with a breakdown in the chain of reference. Despite the somehow optimistic observation that the chain breakdown was successfully rebuild, the case study shows also how the tragedy of Holocaust destroyed the cultural practices of the European Jews. Tracking the chain of references between the pre-war Jewish papercut and the Israeli one always confronts us with the fact that majority of the artists was murdered during the Second World War and their works were destroyed.

Tracing the local connections without dividing it to "global", separate areas such as art, craft and academic research enables one to perceive the research practices on papercutting from different perspective. Describing it in "global" categories leads to understanding the research on papercutting as a separate area that only indirectly contributed to the rebirth of this form of art in Israel. The practice of the ethnographic research could be, however, in itself seen as a net of cultivating the heritage of the Jewish culture, directly linked with the papercutting net in Israel. Seeing the acade-

${ }^{61}$ See e.g. B. Latour, Pandora's Hope ..., op. cit., p. 39. 
mic research as a part of the memory cultivating practice transgresses the intuitive assumption that the only aim of academic activities is to reach a new scientific understanding of various phenomena.

Keeping in mind that researchers had an access mainly to the copies of Jewish papercuts, the various efforts made to recreate the research on papercutting show that the so called: "cultural heritage" of European Jews is still an important topic in the modern Israeli society. In compliance with the Actor-Network Theory approach, avoiding sharp oppositions between "macro" and "micro" scale, the "heritage" cannot be described anymore as located in two antithetic realities of small, "local" initiatives, and a "global" official, sociopolitical discourse. It could be rather described as a wide net of human and not-human actors, including local artist, craftsmen, but also their tools, archives, museums, academic researchers or writers.

Tracking the papercutting network in Israel shows the way in which the cultural heritage is cultivated in Israel in general. Focusing on the substantial, material character of reality, the Actor-Network Theory shows that so called "Jewish cultural heritage" in modern Israel consists of number of practical actions: creating art works and their reproductions, keeping them, segregating, describing, as well as researching on the Jewish heritage and writing about it.

The ANT approach gives also some new research perspectives. It would be worth to take a closer look on the social and political consequences of cultivating the Jewish heritage and the memory on the Holocaust through traditional art and craft. The ANT methodology could be also used to research other aspects, related to the modern Israel. In such a culturally, religious and ethnically diversified society, the Latourian attention to details, honest observation and describing accurately interactions between the actors can put a new light on various issues, described so far in different fields such as political science, cultural science, economy or sociology.

\section{Bibliography}

Abriszewski K., Poznanie, zbiorowość, polityka, Universitas, Kraków 2012.

Abriszewski K., Splatajac na nowo ANT, [in:] B. Latour, Splatajac na nowo to, co społeczne. Wprowadzenie do teorii aktora-sieci, Universitas, Kraków 2010.

Cressman D., A Brief Overview of Actor-Network Theory: Punctualization, Heterogeneous Engineering \& Translation, 2009, http://summit.sfu.ca/item/13593 (access: 23.06.18).

Frankel G., Wycinanka żydowska w Polsce, Towarzystwo Ludoznawcze, Lwów 1929.

Frankel G., The Art of Jewish Papercut, MODAN Publishing House, Tel Aviv 1996.

Goldstein M., Kultura i sztuka ludu żydowskiego na ziemiach polskich, Książnica-Atlas, Lwów 1935.

Kien G., Actor-Network Theory: Translation as Material Culture, 2009, https://grantkien.wordpress.com/2013/02/23/actor-network-theory-translation-as-material-culture-by-grant-kien-2009/ (access: 22.08.18). 
Kohl K.H., The Future of Anthropology Lies in Its Own Past: A Plea for the Ethnographic Archive, "Social Research" 2004, Vol. 81 (3).

Latour B., The Pasteurization of France, Harvard University Press, Cambridge, MA-London 1988.

Latour B., Pandora's Hope: Essays on the Reality of Science Studies, Harvard University Press, Cambridge 1999.

Latour B., Reassembling the Social: An Introduction to Actor-Network-Theory, Oxford University Press, New York 2005.

Latour B., Where Are the Missing Masses? The Sociology of a Few Mundane Artifact, [in:] W. Bijker, J. Law (eds.), Shaping Technology/Building Society: Studies in Sociotechnical Change, MIT Press, Cambridge, MA-London 1992.

Latour B., We Have Never Been Modern, Harvard University Press, Cambridge, MA 1993.

Liliental R., Święta żydowskie w przeszłości i w teraźniejszości, Akademia Umiejętności, Kraków 1919.

Manoff M., Theories of the Archive from Across the Disciplines, Portal Libraries and the Academy, 2004, Vol. 4 (1).

Olsen B., Kultura materialna po tekście: przywracanie obecności rzeczom, [in:] E. Domańska (ed.), Teoria wiedzy o przeszłości na tle współczesnej humanistyki, Wydawnictwo Poznańskie, Poznań 2010.

Shadur J., Shadur Y., Jewish Papercut: A History and Guide, Gefen, New York 1994.

Shadur J., Shadur Y., Traditional Jewish Papercuts: An Inner World of Art and Symbol, University Press of New England, Hannover 2002.

Shamir R., Current Flow: The Electrification of Palestine, Stanford University Press, Stanford 2013. 